
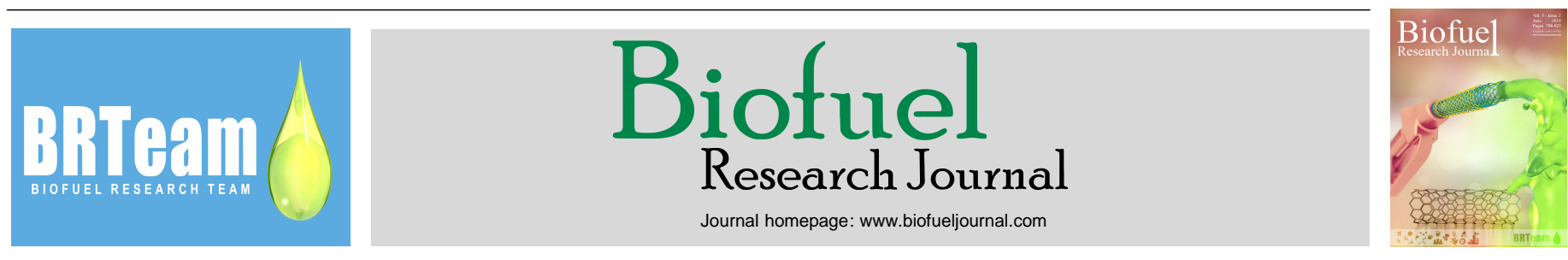

Original Research Paper

\title{
Start-up phase of a two-stage anaerobic co-digestion process: hydrogen and methane production from food waste and vinasse from ethanol industry
}

Grazielle Náthia-Neves ${ }^{1}$, Thiago de Alencar $\mathrm{Neves}^{2}$, Mauro Berni ${ }^{3}$, Giuliano Dragone ${ }^{4}$, Solange I. Mussatto ${ }^{4}$, Tânia Forster-Carneiro ${ }^{1, *}$

${ }^{1}$ Faculty of Food Engineering, University of Campinas (UNICAMP), Rua Monteiro Lobato, 80, 13083-862, Campinas, São Paulo, Brazil.

${ }^{2}$ Faculty of Civil Engineering, Architecture and Town Planning, University of Campinas (UNICAMP), Rua Saturnino de Brito, 224, 13083-889, Campinas, São

Paulo, Brazil.

${ }^{3}$ Interdisciplinary Center of Energy Planning (NIPE), University of Campinas (UNICAMP), Rua Cora Coralina, 13083-970, Campinas, São Paulo, Brazil.

${ }^{4}$ Novo Nordisk Foundation Center for Biosustainability, Technical University of Denmark, Kemitorvet, Building 220, 2800, Kongens Lyngby, Denmark.

\section{HIGHLIGHTS}

A two-stage and semi-continuously anaerobic digestion at pilot scale was designed.

> The system was suitable for co-digestion of food waste and vinasse.

DHigh yield and concentration of hydrogen in the acidogenic reactor was produced.

$>$ The improvement was due to the improved acidogenesis by controlled $\mathrm{pH}$.

\section{GRAPHICAL ABSTRACT}

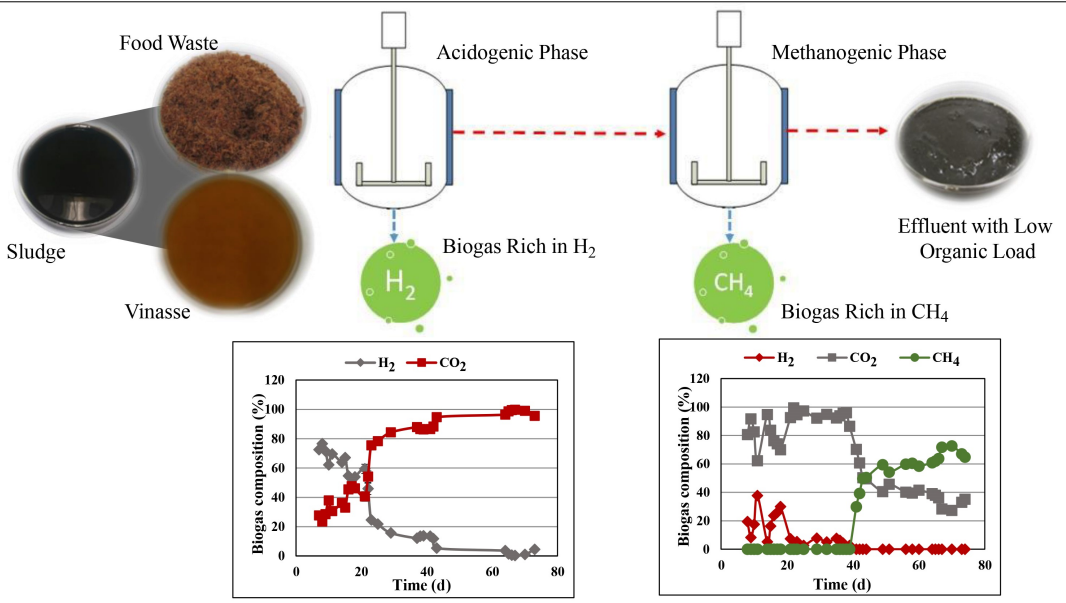

\section{ARTICLE INFO}

\section{Article history:}

Received 25 January 2018

Received in revised form 21 March 2018

Accepted 25 March 2018

Available online 1 June 2018

\section{Keywords:}

Methanogenic

Biogas

Organic residues

Waste treatment

Energy recovery

\begin{abstract}
The start-up conditions of mesophilic anaerobic co-digestion of restaurant food waste and vinasse, a waste from sugarcane industry, was investigated for efficient biogas production. A pilot plant, containing two reactors, was designed and used sequentially and semi-continuously for biogas production. All effective operational parameters were controlled in both reactors over the course of the study. The results indicated that the organic matters were quickly decreased during the start-up phase in the first reactor, resulting in $52 \%$ and $64 \%$ reduction in total solids and total volatile solids, respectively, while the corresponding reductions in the methanogenic reactor were $39.7 \%$ and $51.4 \%$. The production of hydrogen was observed during the first $20 \mathrm{~d}$ of digestion, where the maximum concentration of $76.5 \%$ was detected after $8 \mathrm{~d}$ when the pH stood at 5.96 . After $21 \mathrm{~d}$ of digestion, hydrogen concentration was decreased to less than $4.5 \%$, while methane content was increased leading to an accumulated biogas yield of over $300 \mathrm{~mL}$ per g of total volatile solids. The high concentration of hydrogen in biogas was possibly due to the improvement in the growth of acidogenic bacteria in response to maintaining $\mathrm{pH}$ at their optimum value, leading to a more efficient organic residues hydrolysis.
\end{abstract}

(C) 2018 BRTeam. All rights reserved.

Corresponding author at: Tel.: +55 1935214041

E-mail address: taniafc@unicamp.br

Please cite this article as: Náthia-Neves G., de Alencar Neves T., Berni M., Dragone G., Mussatto S.I., Forster-Carneiro T. Start-up phase of a two-stage anaerobic co-digestion process: hydrogen and methane production from food waste and vinasse from ethanol industry. Biofuel Research Journal 18 (2018) 813-820. DOI: 10.18331/BRJ2018.5.2.5 


\section{Introduction}

Throughout the world today, alternative technologies to fossil fuels and the development of clean and renewable energies (hydro, wind, solar, geothermal, wave, and biomass power) are being sought, due to climate change resulting from the increase of the greenhouse effect. One of the available technologies is anaerobic digestion (AD) which allows energy to be produced in the form of biogas (mainly composed by methane and carbon dioxide as well as traces of nitrogen, hydrogen sulfide, and hydrogen) during the process of anaerobic degradation of organic matter (Campuzano and González-Martínez, 2015; Han et al., 2015). Nowadays, an excess of food waste is generated in the food industry. Food waste, rich in carbohydrates, lipids, and proteins (Han et al., 2015), is also discarded by the general population on a daily basis, especially in developing countries where food waste represents about $70 \%$ of household waste (Xu et al., 2016).

In addition to food waste, Brazil, as the largest producer of sugarcane, is faced by a large deal of the waste from sugarcane activities (Moraes et al., 2015). One type of waste generated by sugarcane industries is vinasse, an effluent from the alcohol distillation process currently used as a fertilizer in the sugarcane fields located near distilleries (Gurgel et al., 2015; Moraes et al., 2015). However, extensive use of vinasse in the soil can cause serious environmental impacts, such as the contamination of groundwater and rivers, due to excess salts and the accumulation of organic matter in the soil (Moraes et al., 2015). Food waste and vinasse are rich in organic matter and therefore, constitute excellent substrates for biogas production through AD.

Technically, $\mathrm{AD}$ is a biotechnological process that occurs in the absence of oxygen (Kythreotou et al., 2014), allowing high-strength organic wastes to be treated while generating energy, i.e., biogas. $\mathrm{AD}$ process involves four steps: hydrolysis, acidogenesis, acetogenesis, and methanogenesis (Moraes et al., 2015). These stages are interconnected, where the products formed in one step are used as substrates in the subsequent step (Shah et al., 2015). $\mathrm{H}_{2}$ is generated during the acidogenic and acetogenic stages while $\mathrm{CH}_{4}$ is produced in the last stage by methanogenic archaea. The process can be improved by the codigestion of two or more substrates, as this provides an increase in the yield of biogas by balancing the carbon/nitrogen $(\mathrm{C} / \mathrm{N})$ ratio necessary for the microbial growth (Gomez-Romero et al., 2014; Shah et al., 2015). This technology can be developed using psychotrophic, mesophilic and thermophilic microorganisms (Kothari et al., 2014). It can also occur in single-stage or twostage systems. In a single-stage, all metabolic reactions involved occur in a single reactor, whereas in two-stage systems, at least two reactors are needed to separate the main reactions (acidogenic and methanogenic) involved in the process (Kothari et al., 2014). The advantages of two-stage systems are: greater stability of the process, better $\mathrm{pH}$ control, increased biogas production, improved activity of methanogenic archaea, as well as better removal of pathogens (Ariunbaatar et al., 2014).

The hydrogen obtained from anaerobic digestion is also considered as an alternative energy resource and applied in different forms for heating or electric energy generation. Additionally, during its combustion hydrogen does not generate any by-products other than water vapor (Gomez-Romero et al., 2014; Han et al., 2015). In general, hydrogen can be produced from fossil fuels, water, or biomass (Stiegel and Ramezan, 2006). Both biomethane and biohydrogen generated from waste feedstock are renewable energy carriers offering environmental advantages such as reduced consumption of fossil fuels and subsequent decreases in the associated emissions on one hand and reduced pollution caused by organic waste through their efficient management and valorization (Chandra et al., 2012). It should be mentioned that co-digestion of waste feedstock could be a reliable strategy to address the disadvantages associated with single substrate digestion systems. In line with that, valorization of two different residues generated in large quantities in the State of São Paulo, Brazil, i.e., vinasse from the ethanol industry and food waste, were investigated in the present study. More specifically, the start-up phase of the two-stage anaerobic co-digestion of these waste feedstocks was evaluated by analyzing the efficiency of the process in terms of the removal of organic matter and production of biogas.

\section{Materials and Methods}

\subsection{Substrate and inoculum}

Food waste was obtained from a restaurant located at the State University of Campinas (Unicamp), Brazil. The food waste was triturated in a blender and was then stored at $-14 \pm 2{ }^{\circ} \mathrm{C}$ until further use. Mesophilic anaerobic sludge obtained from a vinasse treatment facility located in a sugarcane industrial plant in Cosmópolis, São Paulo, Brazil, was used as inoculum. Table 1 presents the characterization of food waste, vinasse, and the inoculum used in the anaerobic co-digestion process.

Table 1.

Characteristics of food waste, Vinasse, and the inoculum used.

\begin{tabular}{llll}
\hline \multirow{2}{*}{ Analytical parameters } & \multicolumn{2}{c}{ Feedstock } & Inoculum \\
\cline { 2 - 3 } & Food waste & Vinasse & \\
\hline $\mathrm{pH}$ & 5.89 & 4.37 & 8.68 \\
Density $\left(\mathrm{kg} / \mathrm{m}^{3}\right)$ & $765.30 \pm 0.01$ & $981.22 \pm 0.02$ & $977.40 \pm 0.01$ \\
Moisture $(\%)$ & $25.3 \pm 0.6$ & $97.92 \pm 0.04$ & $96.86 \pm 0.03$ \\
TS $(\%)$ & $74.7 \pm 0.6$ & $2.08 \pm 0.04$ & $3.14 \pm 0.03$ \\
TS $(\mathrm{g} / \mathrm{Kg})$ & $746 \pm 1$ & $20.8 \pm 0.4$ & $31.4 \pm 0.3$ \\
TFS $(\mathrm{g} / \mathrm{Kg})$ & $56 \pm 2$ & $6.3 \pm 0.1$ & $11.2 \pm 0.5$ \\
TVS $(\mathrm{g} / \mathrm{kg})$ & $691 \pm 2$ & $14.5 \pm 0.4$ & $20.3 \pm 0.7$ \\
TKN $(\mathrm{g} / \mathrm{kg})$ & $27.3 \pm 0.5$ & $0.4 \pm 0.1$ & $0.8 \pm 0.3$ \\
Protein $(\mathrm{g} / \mathrm{kg})$ & $171 \pm 3$ & $2.4 \pm 0.4$ & $5 \pm 2$ \\
Ammonium nitrogen $(\mathrm{mg} / \mathrm{L})$ & $315.00 \pm 0.05$ & $56.00 \pm 0.02$ & $280.00 \pm 0.02$ \\
COD $(\mathrm{gO} / \mathrm{L})$ & $61 \pm 2$ & $21.8 \pm 0.6$ & $9.1 \pm 0.8$ \\
TOC $(\mathrm{g} / \mathrm{L})$ & 92.25 & 6.47 & 0.80 \\
Alkalinity $(\mathrm{mg} \mathrm{CaCO} / \mathrm{L})$ & $76.0 \pm 0.2$ & $6.0 \pm \pm 0.3$ & $417 \pm 1$ \\
\hline
\end{tabular}

TS: Total solid; TVS: Total volatile solid; TFS: Total fixed solid; TKN: Total Kjeldahl nitrogen; COD: Chemical oxygen demand; TOC: Total organic carbon

\subsection{Analytical methods}

\subsubsection{Physicochemical procedures}

The analytical methods used to characterize food waste, vinasse, and the inoculum included $\mathrm{pH}(4500-\mathrm{H}+\mathrm{B})$; total alkalinity (2320B), total solids (TS; 2540B), total volatile solids (TVS; 2540E), total Kjeldahl nitrogen (TKN; 4500Norg-B), ammonium nitrogen (45000NH3-C), total dissolved organic carbon (5310B), and chemical oxygen demand (COD; 4520D); according to the Standard Methods for the Examination of Water and Wastewater (APHA, 1998). Proteins were determined by multiplying the TKN content by 6.25 (AOAC, 1997).

\subsubsection{Sample preparation}

For the analysis of ammonium nitrogen, alkalinity, total organic carbon (TOC), and COD, the samples were diluted in deionized water and stirred at $150 \mathrm{rpm}$ for $2 \mathrm{~h}$. Then, the samples were filtered through $3.0 \mu \mathrm{m}$ filter papers and analyzed. For the analysis of both TS and TVS, undiluted samples were used. For the volatile fatty acids (VFA) analysis, approximately $2 \mathrm{~g}$ of samples were weighed and subsequently extracted with hexane $(20 \mathrm{~mL})$ using a vortex mixer. Finally, $1 \mathrm{~mL}$ of phosphoric acid $(3 \mathrm{~mol} / \mathrm{L})$ was added to the mixture (sample + hexane) in order to acidify the sample and allow the vaporization of the VFA in the gas chromatograph injector.

\subsection{Gas chromatographic analysis}

\subsubsection{Volatile fatty acids (VFA)}

VFA (acetic, propionic, butyric, and valeric acids) were determined by a gas chromatograph (GC) coupled to a mass spectrometer (GC-MS, Shimadzu Corporation, Japan) using a method adapted from Liu et al (2008). The GC-MS was equipped with a capillary column DB-WAX (Agilent Technologies) with the following dimensions: length of $30 \mathrm{~m}$, internal diameter of $0.25 \mathrm{~mm}$, and film thickness of $20 \mu \mathrm{m}$. The carrier gas 
was helium at a flow rate of $1 \mathrm{~mL} / \mathrm{min}$. Samples were injected manually with a Hamilton gas-tight syringe. The injection volume was $2 \mu \mathrm{L}$ per sample in Split mode (1:100). The temperature of the injector was maintained at $250{ }^{\circ} \mathrm{C}$. An isotherm of $80{ }^{\circ} \mathrm{C}$ (held for $3 \mathrm{~min}$ ) up to $180{ }^{\circ} \mathrm{C}$ at $15{ }^{\circ} \mathrm{C} / \mathrm{min}$ (held for $2 \mathrm{~min}$ ) was used for VFA separation in the analytical column. A mass range of $\mathrm{m} / \mathrm{z} 12$ to $\mathrm{m} / \mathrm{z} 120$ was used to develop analytical curves for each VFA. A working solution of $10 \mathrm{~g} / \mathrm{L}$ of VFA was used for the construction of all analytical curves.

\subsubsection{Biogas}

Biogas samples were collected directly from acidogenic and methanogenic reactors and injected manually into a GC (GC 2014, Shimadzu Corporation, Japan) equipped with a thermal conductivity detector (TCD) and a packed column for compound separation (ShinCarbon ST 50/80 mesh). To determine biogas composition $\left(\mathrm{H}_{2}, \mathrm{CH}_{4}\right.$, and $\left.\mathrm{CO}_{2}\right)$, the following chromatographic conditions were used: temperatures of the injection port and detector were both set to $200{ }^{\circ} \mathrm{C}$; initial temperature of $\mathrm{GC}$ column was $50{ }^{\circ} \mathrm{C}$ (held for $3 \mathrm{~min}$ ), and then increased by $5{ }^{\circ} \mathrm{C} / \mathrm{min}$ to $180{ }^{\circ} \mathrm{C}$ and then held for $5 \mathrm{~min}$. The sample volume injected was $0.5 \mathrm{~mL}$, and $\mathrm{N}_{2}$ was used as a carrier gas $(35 \mathrm{~mL} / \mathrm{min}, 5$ bar).

The volume of biogas was measured using the inverted test tube method. Briefly, this method consists of filling the entire volume of a graduated cylinder with water, and then inverting it over a beaker of water. A hose to the outlet of the reactor gas is introduced into the bottom of the graduated cylinder. As the gas enters the hose, water is displaced from the graduated cylinder. This water displacement is equal to the volume of gas produced in the reactor. The cumulative volume and cumulative yield of biogas were calculated according to Equations 1 and 2, respectively, where, "Y" is yield, "V" is volume, " $\mathrm{gTVS}_{\text {add }}$ " is the amount of TVS added in the reactors and "n" is the number of days.

$\mathrm{V}_{\text {accumulated }}(\mathrm{mL})=\sum_{\mathrm{n}=1}^{\mathrm{n}} \mathrm{V}_{\mathrm{n}}$

$\mathrm{Y}_{\text {accumulated }}\left(\frac{\mathrm{mL}_{\text {biogas }}}{\mathrm{gTVS}_{\text {add }}}\right)=\sum_{\mathrm{n}=1}^{\mathrm{n}} \frac{\mathrm{V}_{\mathrm{n}}}{\mathrm{gTVS}_{\text {add }}}$

\subsection{Reactor configuration and operational conditions}

The two-stage anaerobic co-digestion was performed in 4300-mL stainless steel reactors operated under a semi-continuous regime and mesophilic condition at $37.0 \pm 2{ }^{\circ} \mathrm{C}$ (Fig. 1). The semi-continuous regime was operated with inputs and outputs in batch mode. These reactors were kept under constant stirring $(50 \mathrm{rpm})$ to ensure sufficient mixing. The working volume of each reactor was $60 \%$ of total volume $(2580 \mathrm{~mL}$ or $20 \%$ $(\mathrm{v} / \mathrm{v})$ food waste and $40 \%$ mesophilic sludge) with enough headspace for gas production ( $40 \%$ headspace). For the semi-continuous regime in the acidogenic reactor, a quantity of $50 \mathrm{~mL}$ was withdrawn at the same time that the reactor was fed with $50 \mathrm{~mL}$ of food waste, vinasse, and inculum, at regular intervals ( $3 \mathrm{~d}$ ). For the semi-continuous regime in the methanogenic reactor, $50 \mathrm{~mL}$ of effluent discarded from the acidogenic reactor was introduced into the reactor, which was fed at the same time that $50 \mathrm{~mL}$ was withdrawn in order to maintain the mass balance.

Temperature and $\mathrm{pH}$ of the acidogenic reactor were constantly monitored by an online system. A peristaltic pump was programmed to release $1.0 \mathrm{~N} \mathrm{HCl}$ or $1.0 \mathrm{~N} \mathrm{NaOH}$ to maintain the $\mathrm{pH}$ of the medium in the range of $5.5-6.5$. Temperature and $\mathrm{pH}$ in the methanogenic reactor were also controlled, and the $\mathrm{pH}$ was adjusted in the range of $6.5-7.5$. A thermostat bath was used to keep the temperature inside the reactors at 37.0 $\pm 2{ }^{\circ} \mathrm{C}$. Over the days of the experiment, small amounts of samples were collected from the reactors in order to evaluate the process performance in terms of TS, TVS, COD, TOC, VFA, alkalinity, and ammonium nitrogen.

\section{Results and Discussion}

\subsection{Removal of TS, TVS, COD, and TOC in acidogenic and methanogenic reactors}

The TS, TVS, COD, and TOC removal are important parameters for evaluating the efficiency of microbial activity in the degradation of the substrates involved in the AD. The contents of TS, TVS, COD, and TOC in the acidogenic and methanogenic reactors during the present study are shown in Figure 2. As can be seen, all these parameters were reduced in both reactors over the operation days.

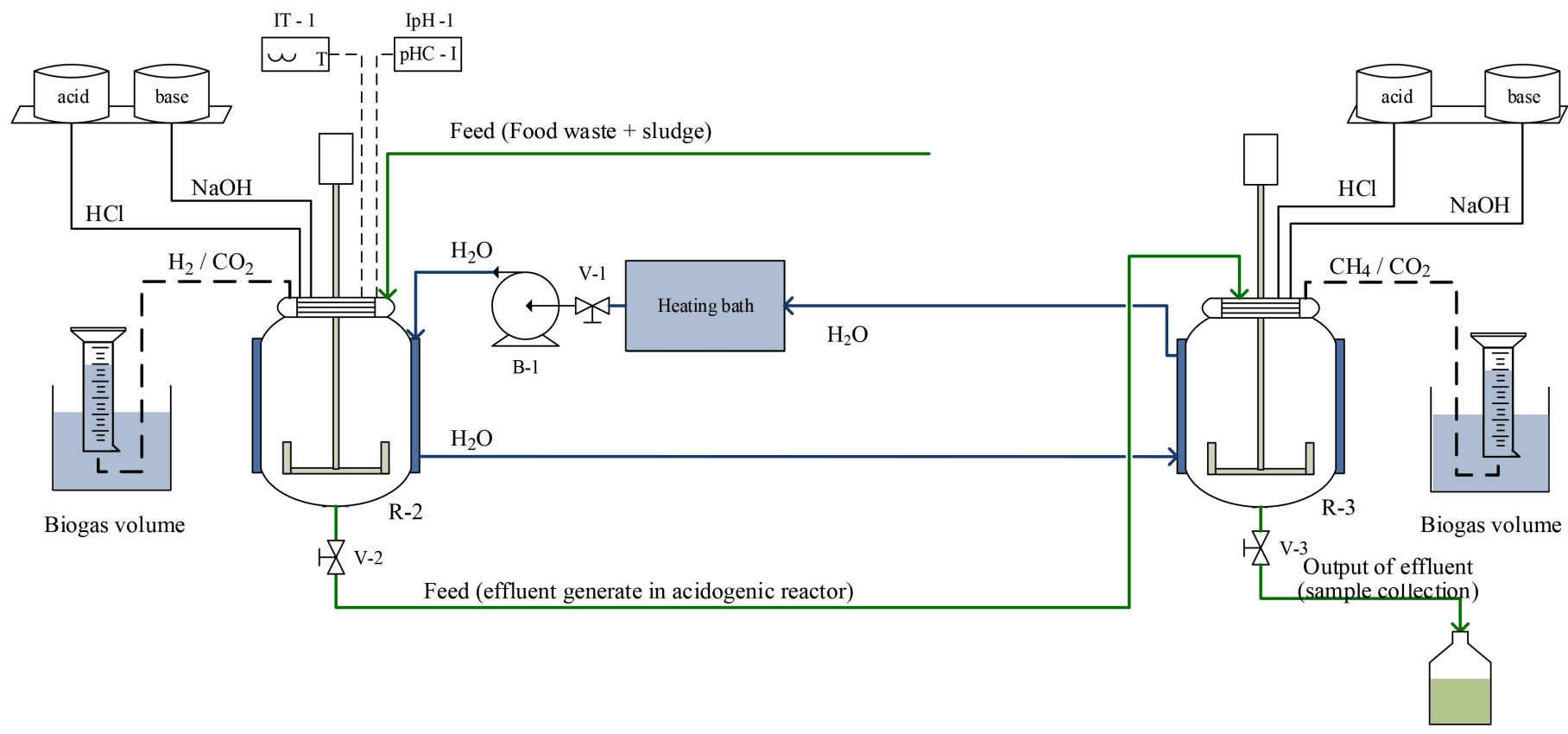

Fig.1. Flowchart of the anaerobic digestion system used. V-1 to V-3: Blocking valves; B-1: Pump; R- 1: Reactor used for the acidogenic phase; R-2: Reactor used for the methanogenic phase; IpH: indicators of $\mathrm{pH}$; IT: indicators of temperature. 
During the start-up phase, the TS and TVS contents in the acidogenic reactor (Fig. 2a) were quickly decreased. These results indicated high microbial activities in the initial stages of $\mathrm{AD}$ where bacteria hydrolyze complex compounds into simpler compounds, reducing the solids present in the system. At the end of the acidogenic process, TS and TVS were considerably reduced by $52 \%$ and $64 \%$, respectively. The TS and TVS reductions observed in the methanogenic reactor were $39.68 \%$ and $51.42 \%$, respectively (Fig. $2 b$ ).

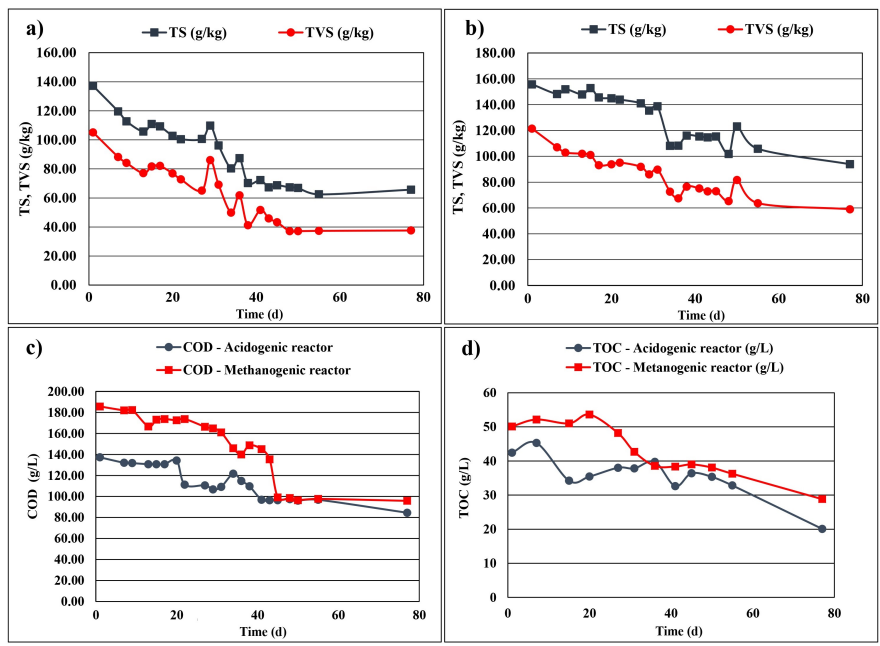

Fig.2. Variations in total solids (TS) and total volatile solids (TVS) in a) the acidogenic reactor and b) in the methanogenic reactor. Variations in c) chemical oxygen demand (COD) and d) total organic carbon (TOC), in the acidogenic and methanogenic reactors.

Similar trend of TS reduction (i.e., 37.48\%) was found by Dareioti and Kornaros (2015) during the co-digestion of ensiled sorghum (55\%), cheese whey $(40 \%)$, and liquid cow manure $(5 \%)$ at $37{ }^{\circ} \mathrm{C}$ and $\mathrm{pH} 8.0$; however, the TVS reduction reported by these authors was higher $(65.97 \%)$ than in the present study. Jabeen et al. (2015) studied the co-digestion of food waste and rice husks with dry manure under methanogenic conditions at $37{ }^{\circ} \mathrm{C}$ and achieved TVS reduction of $82.41 \%$. In a different study, Liu et al. (2013) observed a reduction of $30.70 \%$ in the TVS content during the two-stage anaerobic co-digestion of sludge and food waste $(40 \%)$. The considerable variations in the values of TVS reduction reported in the literature can be explained by the fact that the efficiency of solid reduction depends on factors such as the microbial activity, the characteristics of the residue used, and the feed rate of the substrate.

$\mathrm{COD}$ is another important parameter for $\mathrm{AD}$, which represents the extent of solubilization of the waste used. The COD of the acidogenic reactor reduced from $137.25 \mathrm{~g} / \mathrm{L}$ to $84.42 \mathrm{~g} / \mathrm{L}$ (reduction of $38.49 \%$ ) (Fig. 2c). The COD reduction in the methanogenic reactor was $48.41 \%$ (from 185.65 to $95.77 \mathrm{~g} / \mathrm{L}$ ). The differences in COD reductions in the reactors can be explained by the way they were fed. While the acidogenic reactor was fed with food waste and sludge, the methanogenic reactor was fed with biodigested material from the acidogenic reactor. Higher COD content reductions in methanogenic reactors than in acidogenic reactors during the two-stage anaerobic digestion of different residues has also been reported by other authors. Mamimin et al. (2015), for example, studied the two-stage AD of palm oil effluent and observed a COD content removal of $38 \%$ in the acidogenic reactor, and $95 \%$ in the methanogenic reactor. During the two-stage AD of potatoes at $35^{\circ} \mathrm{C}$, Zhu et al. (2008) observed a COD reduction of $51 \%$ in the acidogenic reactor and $62 \%$ in the methanogenic reactor. The possibility of achieving higher reductions in organic matter contents by using multiple-stage reactor systems is the major motivation behind using such systems for biogas production. In better words, these system make possible obtaining energy from waste feedstocks while at the same time, generate an effluent with low organic load which can be used as fertilizer in agricultural activities.
The $\mathrm{AD}$ of solid residual kitchen waste at $41{ }^{\circ} \mathrm{C}$ and alkaline $\mathrm{pH}$ (substrate ratio of 1:2.1) led to $35 \%$ and $48 \%$ reductions in TS and TVS contents, respectively (Gao et al., 2015). The co-digestion of food waste performed in the methanogenic reactor in this study reduced TS by $39 \%$ and TVS by $51 \%$. Another study involving digestion of food waste only, using yeast as inoculum, promoted a reduction between $30-50 \%$ in COD content (Suwannarat and Ritchie, 2015). These values are close to the range reported in the present study, where COD reductions of $38 \%$ and $48 \%$ were obtained in the acidogenic and methanogenic reactors, respectively. This shows that the co-digestion of food waste with vinasse had a positive impact on solid and organic matter removal when compared to digestion only of the food waste.

Finally, the TOC reductions in the acidogenic and methanogenic reactors throughout the experiment are shown in Figure 2d. TOC content in the acidogenic reactor was reduced by $52.66 \%$ (from $42.42 \mathrm{~g} / \mathrm{L}$ to $20.08 \mathrm{~g} / \mathrm{L}$ ), while in the methanogenic reactor, this parameter was reduced by $42.48 \%$ (from $50.11 \mathrm{~g} / \mathrm{L}$ to $28.81 \mathrm{~g} / \mathrm{L}$ ). These values can be well compared to those reported in the literature. For example, Cheng and Liu (2002) studied the digestion of pig wastewater at $35{ }^{\circ} \mathrm{C}$ under methanogenic conditions and obtained a TOC content reduction of $35 \%$, lower than what obtained in the present study (42.48\%). During the production of hydrogen through tofu wastewater, Zhu et al. (1999) obtained $41 \%$ TOC content reduction, which is also lower than the value obtained herein $(52.66 \%)$.

\subsection{Evolution of pH and concentration of inhibitors throughout the process}

The $\mathrm{pH}$ of the acidogenic and methanogenic reactors was controlled at $5.5-6.5$ and $6.5-7.5$, respectively, since these ranges meet the requirements of microorganisms for produceing $\mathrm{H}_{2}$ (acidic $\mathrm{pH}$ ) and $\mathrm{CH}_{4}$ (alkaline $\mathrm{pH}$ ), respectively. As can be seen in Figures $3 \mathrm{a}$ and $\mathrm{b}$, the $\mathrm{pH}$ of both reactors were remained within the established ranges throughout the process.

Alkalinity and ammonium nitrogen are important parameters for maintaining the buffering capacity of anaerobic systems. Buffered systems, in turn, provide higher stability for the microorganisms as abrupt $\mathrm{pH}$ changes will be avoid. According to Li et al. (2015), stable systems operate with total alkalinity values between $1000-3000 \mathrm{mg} \mathrm{CaCO} / / \mathrm{L}$. In the present study, the alkalinity of both reactors remained within this range during most of the operation time (Figs. 3a and b). However, the methanogenic reactor showed higher alkalinity values compared with the acidogenic reactor, with values ranging between 2223 and $3804 \mathrm{mg} \mathrm{CaCO} / / \mathrm{L}$ against 616 and 1655 $\mathrm{mg} \mathrm{CaCO}_{3} / \mathrm{L}$. Such results were expected as methanogenic phase occurs at alkaline $\mathrm{pH}$. Similar results (i.e., alkalinity of $3000 \mathrm{mg} \mathrm{CaCO} / \mathrm{L}$ at $\mathrm{pH}$ values between 6.1 and 7.4) were also reported by Montañés et al. (2013), during the co-digestion of beet pulp leachate with sewage sludge at $35^{\circ} \mathrm{C}$. Higher values (i.e., $4444-5146 \mathrm{mg} \mathrm{CaCO}_{3} / \mathrm{L}$ ) were observed by Ratanatamskul et al. (2014) during the co-digestion of food waste with sewage sludge under methanogenic conditions at $35^{\circ} \mathrm{C}$.

The ammonium nitrogen contents $\left(\mathrm{mg} \mathrm{N}-\mathrm{NH}_{3} / \mathrm{L}\right)$ in the acidogenic and methanogenic reactors are shown in Figure 3e. As presented, the ammonium nitrogen content in the acidogenic reactor remained in the range of 1072.40 to $2940.00 \mathrm{mg} \mathrm{N}-\mathrm{NH}_{3} / \mathrm{L}$. The increase in the ammonium nitrogen content occurred due to the degradation of nitrogen compounds (protein) present in the food waste during the hydrolysis stage. The methanogenic reactor presented higher levels of ammonium nitrogen, mainly during the first days of digestion, reaching concentrations higher than $4000 \mathrm{mg} \mathrm{N}-\mathrm{NH}_{3} / \mathrm{L}$. Values of this magnitude can inhibit the action of methanogenic archaea, reducing the production of methane. According to Procházka et al. (2012), the optimal concentrations of ammonium nitrogen for methane production are between 2100 and $3100 \mathrm{mg} \mathrm{N}-\mathrm{NH}_{3} / \mathrm{L}$ According to these authors, high concentrations of ammonium nitrogen (around $4000 \mathrm{mg} \mathrm{N}-\mathrm{NH}_{3} / \mathrm{L}$ ) inhibited the production of methane, while low concentrations $\left(500 \mathrm{mg} \mathrm{N}-\mathrm{NH}_{3} / \mathrm{L}\right)$ decreased methane production. During the production of hydrogen $\left(\right.$ at $37^{\circ} \mathrm{C}$ ) and methane (at $55^{\circ} \mathrm{C}$ ) in a two stage system, Lin et al. (2013) observed that during hydrogen production, the ammonium nitrogen concentration decreased from 1519 to $1118 \mathrm{mg} \mathrm{N}$ $\mathrm{NH}_{3} / \mathrm{L}$, while during the methane production, this value was increased from 1157 to $2008 \mathrm{mg} \mathrm{N}-\mathrm{NH}_{3} / \mathrm{L}$, indicating a higher decomposition of protein and urea by the methanogenic archaea. 

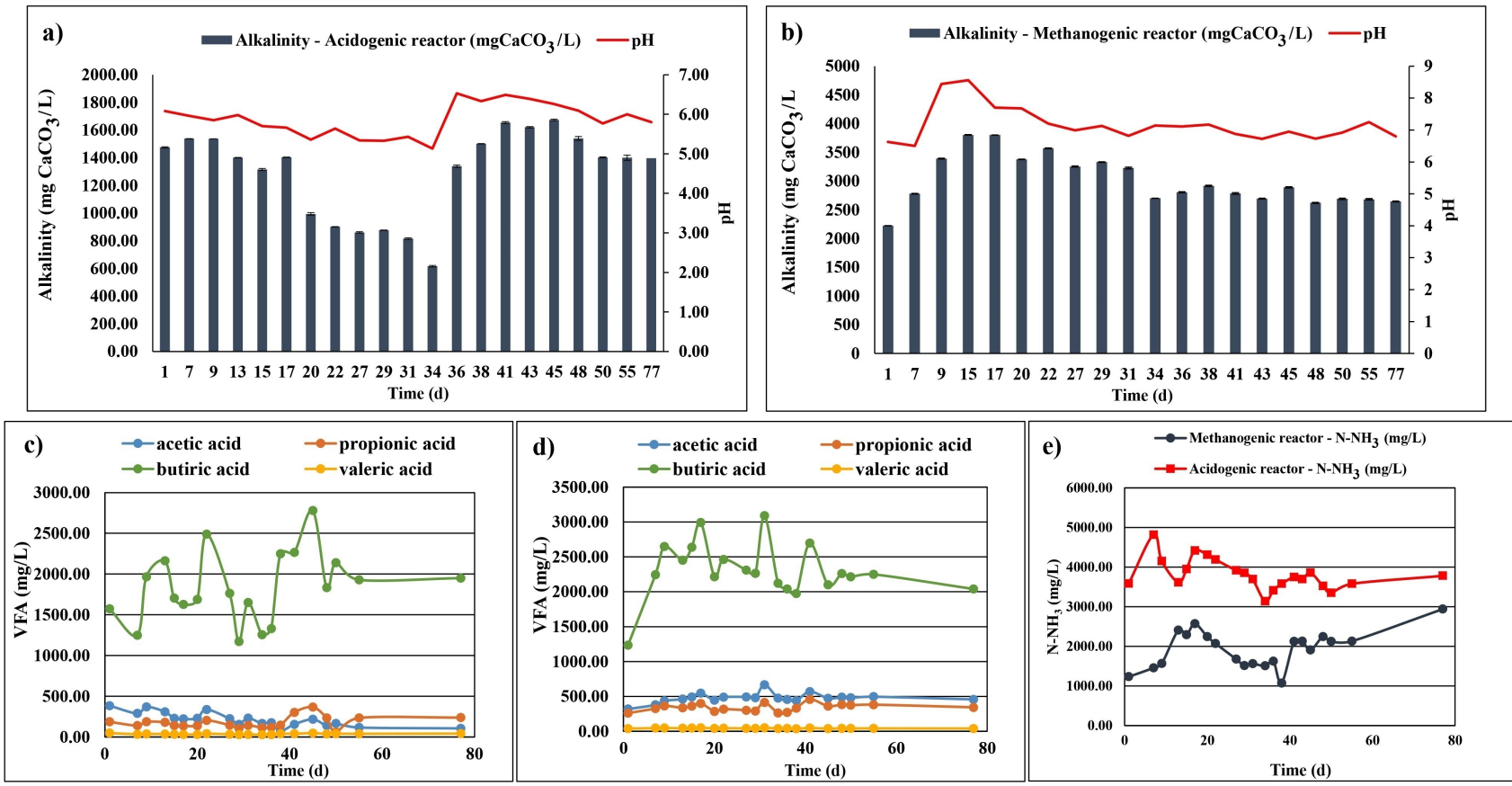

Fig.3. Process inhibitors: variations in alkalinity and $\mathrm{pH}$ in the acidogenic reactor (a) and in the methanogenic reactor (b). Variations in volatile fatty acids (VFA) in the acidogenic reactor (c) and in the methanogenic reactor (d). Variations in ammonium nitrogen content $\left(\mathrm{N}-\mathrm{NH}_{3}\right)$ in acidogenic and methanogenic reactors (e).

VFA production in the acidogenic and methanogenic reactors is depicted in Figures $3 \mathrm{c}$ and $\mathrm{d}$, respectively. None of the reactors presented a stable behavior in terms of VFA production, as the concentrations fluctuated over time. This fluctuation was probably resulting from the semi-continuous feeding and the complex nature of the organic materials used for loading the systems. In the acidogenic reactor, for example the concentration of acetic acid ranged from 74.54 to $383.46 \mathrm{mg} / \mathrm{L}$, while the concentration of propionic acid varied from 58.30 to $365.78 \mathrm{mg} / \mathrm{L}$, and the concentration of butyric acid strongly varied from 1169.81 to $2777.96 \mathrm{mg} / \mathrm{L}$ (Fig. 3c). Valeric acid was present in lower concentrations when compared with the others VFAs, ranging from 26.51 to $47.85 \mathrm{mg} / \mathrm{L}$, only. Comparable results on VFA production were reported by Zhu et al. (2008) during the AD of potatoes waste at $\mathrm{pH} 5.5(1866 \mathrm{mg} / \mathrm{L}$ of acetic acid, $232 \mathrm{mg} / \mathrm{L}$ of propionic acid, $1372 \mathrm{mg} / \mathrm{L}$ of butyric acid, and 149 $\mathrm{mg} / \mathrm{L}$ valeric acid).

Figure 3d shows the VFAs production in the methanogenic reactor. The concentration of acetic acid in this reactor ranged from 319.43 to $666.30 \mathrm{mg} / \mathrm{L}$, while the concentration of propionic acid varied from 260.03 to $456.91 \mathrm{mg} / \mathrm{L}$, butyric acid from 1234.60 to $3089.30 \mathrm{mg} / \mathrm{L}$, and valeric acid from 38.07 to $50.89 \mathrm{mg} / \mathrm{L}$. In general, the accumulation of VFAs is highly unfavorable to the activity of methanogenic archaea. The accumulation of propionic acid, for example, inhibits the metabolism of these microorganisms and may cause an intensification of all VFAs leading to a complete system imbalance (Ariunbaatar et al., 2015). According to Montanes et al. (2013), the metabolism of methanogenic archaea is inhibited by propionic acid concentrations of about $3000 \mathrm{mg} / \mathrm{L}$ and among all the VFAs produced during AD, acetic acid is the least toxic one to biogas production. Similar to the acidogenic reactor, butyric acid was also the VFA produced in the highest quantity in the methanogenic reactor, reaching the concentration of $3089.30 \mathrm{mg} / \mathrm{L}$ (Fig. 3d). This value is similar to that $(3720.00 \mathrm{mg} / \mathrm{L})$ reported by Dareioti and Kornaros (2014) during the $\mathrm{AD}$ of ensiled sorghum (55\%), whey (40\%), and liquid cow manure $(5 \%)$ at $37^{\circ} \mathrm{C}$ by methanogenic archaea.

\subsection{Biogas production}

The composition, the accumulated volume, and the cumulative yield of biogas obtained in the acidogenic reactor are shown in Figures 4a and b. As can be seen in Figure 4a, the production of hydrogen occurred during the first $20 \mathrm{~d}$ of the process, with the maximum concentration $(76.54 \%)$ recorded on the $8^{\text {th }}$ day, at $\mathrm{pH}$ 5.96. During this period (initial $8 \mathrm{~d}$ ), ammonia production was in the range of 1230-1570 mg/L. While the maximum concentration of $\mathrm{H}_{2}$ occurred in the early days of the experiment, the TVS and COD reductions measured were low, corresponding to $17.78 \%$ and $4 \%$, respectively. After the $21^{\text {st }}$ day, hydrogen concentration decreased, reaching $4.46 \%$ at the end of the process. The volume of biogas accumulated in the acidogenic reactor throughout the experiment corresponded to $5647 \mathrm{~mL}$ and the biogas yield was $300.64 \mathrm{~mL} / \mathrm{gTVS}_{\text {add }}$ (Fig. 4b). It is worth noting that the majority of the biogas produced in this reactor was contributed by $\mathrm{CO}_{2}$, and that the main objective of this reactor was not to produce high biogas yields, but rather to generate an effluent to be used in the subsequent reactor as substrate by the methanogenic archaea to produce a methane-containing biogas.

The biogas composition in the acidogenic reactor ranged from 59-72\% $\mathrm{H}_{2}$ during the initial $20 \mathrm{~d}$. Lower values have been reported in the literature, for example, Valdez-Vazquez et al. (2005) obtained a biogas with 58\% of hydrogen during the digestion of organic fraction of municipal waste. A biogas with $64 \%$ of hydrogen was obtained by Cappai et al. (2015) during food waste fermentation at $39{ }^{\circ} \mathrm{C}$. The $\mathrm{AD}$ of food waste and sludge obtained from a wastewater treatment performed by $\mathrm{Chu}$ et al. (2008) resulted in a biogas with 52-56\% of hydrogen. The higher concentration of hydrogen in biogas obtained in this study compared whit the concentrations reported in the literature was possibly due to the fact that the growth of acidogenic bacteria was promoted by maintaining the $\mathrm{pH}$ low, leading to a more efficient hydrolysis of the solid organic residues of food waste. The fermentative hydrolytic bacteria break down proteins, lipids, and carbohydrates into less complex substances (i.e., amino acids, fatty acids, and monosaccharides). These results confirmed that the activity of the hydrogenase enzyme is strongly influenced by the $\mathrm{pH}$, and low $\mathrm{pH}$ values favor the production of biohydrogen.

Hydrogen production decreased in the methanogenic reactor as the proportion of methane in the biogas increased (Fig. 4c). More specifically, during the first $20 \mathrm{~d}$, organic acids were converted into hydrogen and carbon dioxide through the action of acetogenic bacteria (known as hydrogen producers), while acetic acid was produced by the homoacetogenic bacteria. By continuing the methanogenesis stage, methane was formed from acetic acid by the action of acetoclastic 

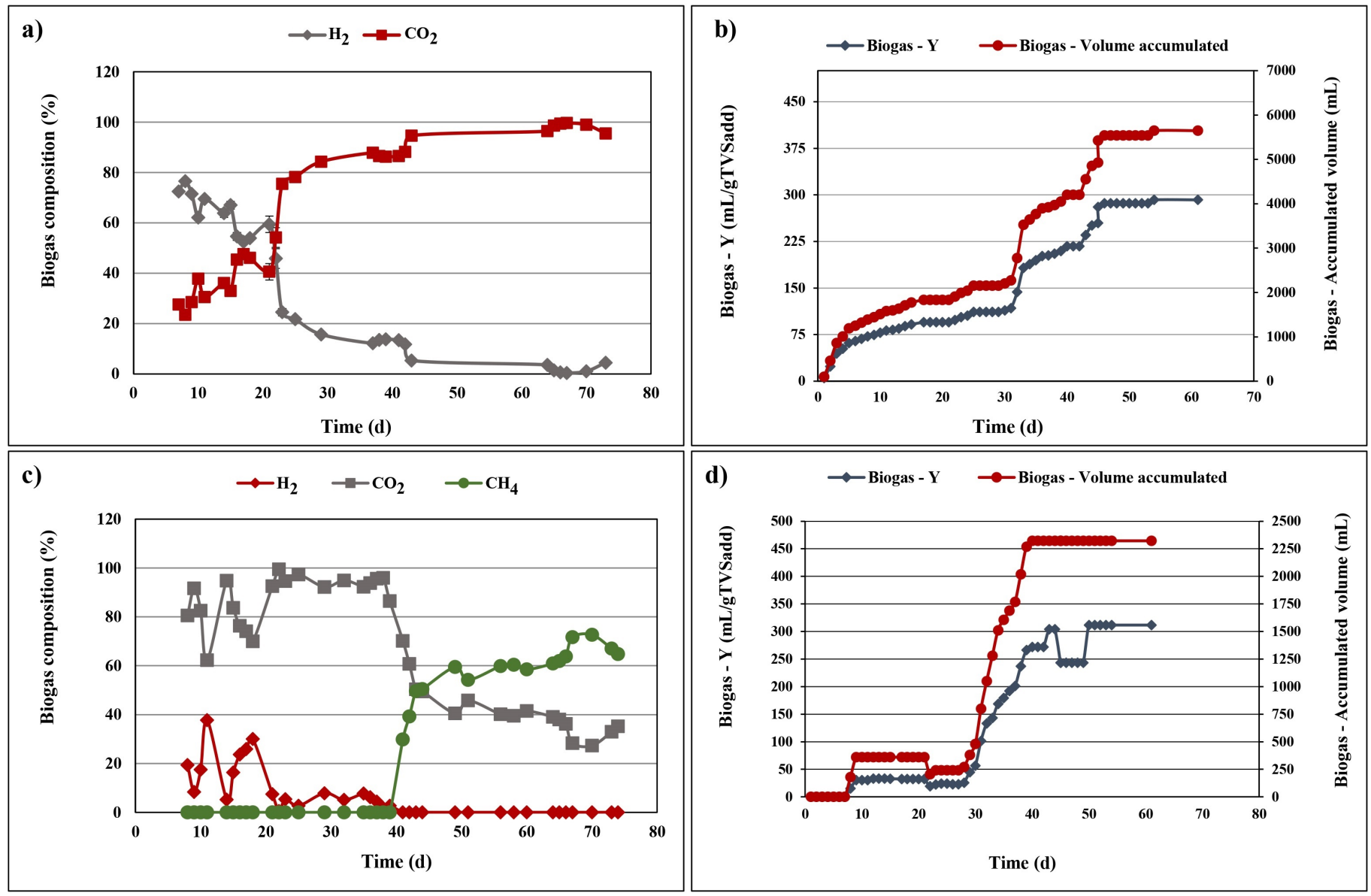

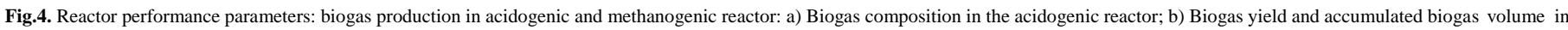
the acidogenic reactor; c) Biogas composition in the methanogenic reactor; and d) Biogas yield and accumulated biogas volume in the methanogenic reactor.

Table 2.

Summary of the values of the parameters recorded for the reactors at the beginning and at the end of the experiments (mean values \pm standard deviations).

\begin{tabular}{|c|c|c|c|c|}
\hline \multirow{2}{*}{ Parameters } & \multicolumn{2}{|c|}{ Beginning ( $\left(1^{\text {st }}\right.$ day of the experiment) } & \multicolumn{2}{|c|}{ End $\left(77^{\text {th }}\right.$ day of the experiment) } \\
\hline & Acidogenic reactor & Methanogenic reactor & Acidogenic reactor & Methanogenic reactor \\
\hline $\mathrm{pH}$ & 5.96 & 6.63 & 5.98 & 7 \\
\hline Moisture (\%) & $86.28 \pm 0.06$ & $84.24 \pm 0.35$ & $93.43 \pm 0.04$ & $90.61 \pm 0.06$ \\
\hline TS $(\%)$ & $13.72 \pm 0.06$ & $15.76 \pm 0.35$ & $6.57 \pm 0.04$ & $9.39 \pm 0.06$ \\
\hline TS $(g / K g)$ & $137.16 \pm 0.55$ & $155.76 \pm 1.90$ & $65.71 \pm 0.38$ & $93.94 \pm 0.60$ \\
\hline TVS $(g / K g)$ & $105.13 \pm 0.69$ & $121.49 \pm 1.87$ & $37.63 \pm 0.52$ & $59.02 \pm 1.12$ \\
\hline TKN & $7.42 \pm 1.39$ & $7.42 \pm 1.39$ & $4.19 \pm 0.05$ & $7.26 \pm 0.77$ \\
\hline Ammonium nitrogen $(\mathrm{mg} / \mathrm{L})$ & $1232.28 \pm 0.40$ & $3584.56 \pm 0.79$ & $2940.00 \pm 7.3$ & $3780 \pm 39.60$ \\
\hline TOC $(g / L)$ & 34.20 & 50.11 & 20.09 & 36.25 \\
\hline $\mathrm{COD}\left(\mathrm{gO}_{2} / \mathrm{L}\right)$ & $137.25 \pm 7.63$ & $185.65 \pm 5.62$ & $84.42 \pm 2.24$ & $95.77 \pm 2.85$ \\
\hline Alkalinity $\left(\mathrm{mg} \mathrm{CaCO}_{3} / \mathrm{L}\right)$ & $1474.93 \pm 5.11$ & $2223.15 \pm 1.31$ & $1396.25 \pm 1.77$ & $2644.51 \pm 7.00$ \\
\hline
\end{tabular}

TS: Total solid; TVS: Total volatile solid; TKN: Total Kjeldahl nitrogen; COD: Chemical oxygen demand; TOC: Total organic carbon 
methanogenic archaea, as well as from $\mathrm{H}_{2}$ and $\mathrm{CO}_{2}$ by the action of hydrogenotrophic methanogenic archaea.

The composition, the accumulated volume, and the cumulative yield of biogas obtained in the methanogenic reactor are shown in Figures $4 \mathrm{c}$ and $\mathrm{d}$. Initially, only $\mathrm{H}_{2}$ and $\mathrm{CO}_{2}$ were produced in this reactor (Fig. 4c). The production of methane just started when hydrogen production ceased on the $41^{\text {st }}$ day. Then, methane proportion increased over time, reaching the maximum value of $72.70 \%$ after $70 \mathrm{~d}$ of process, at $\mathrm{pH} 6.82$. The accumulated volume of biogas produced and the yield of biogas in this reactor were recorded at 2322 $\mathrm{mL}$ and $311.41 \mathrm{~mL} / \mathrm{gTVSadd}$, respectively (Fig. 4d). The TVS and COD reductions were $51.42 \%$ and $48.41 \%$, respectively, indicating that the TVS and COD removed were converted into biogas by methanogenic archaea. The methanogenic reactor presented higher values of ammonia nitrogen (higher than $4000 \mathrm{mg} / \mathrm{L}$ ) than the acidogenic reactor, which could have been responsible for the delay in the production of methane. Similar results were reported by Ratanatamskul et al. (2014), who obtained a biogas containing $76.8 \%$ of methane during the co-digestion of food waste with sludge at $35^{\circ} \mathrm{C}$ under methanogenic conditions. Rivero et al. (2014) also obtained a biogas with $62.39 \%$ of methane through the co-digestion of sewage sludge with glycerol under mesophilic conditions and $\mathrm{pH}$ values in the range 7-8.

\subsection{Overall comparison}

Table 2 summarizes the values recorded for the parameters investigated for the different reactors at the beginning and at the end of the anaerobic codigestion. Throughout the experiment, little $\mathrm{pH}$ variation was observed in both reactors, indicating a good buffering capacity of the systems. The moisture content was increased in both reactors and in line with that, a reduction in solid content (TS and TVS) was observed at the end of the experiments. The COD and TOC were decreased in both reactors over the experiments, indicating the degradation of organic matter present in food waste by the microorganisms involved in the process.

\section{Conclusions}

The start-up phase of the two-stage anaerobic co-digestion process was proved to be effective for the reduction of solid (TS and TVS) organic matter (COD and TOC). The TS and TVS of the effluent generated in the first stage were reduced by $52 \%$ and $64 \%$, respectively, constituting an excellent substrate for the production of biogas rich in methane $(72.7 \%)$ in the second stage.

\section{Acknowledgments}

The authors would like to acknowledge the financial support from the São Paulo Research Foundation - FAPESP (2011/19817-1; 2018/05999-0), CNPq (130741/2014-0), and the Novo Nordisk Foundation (Denmark, NNF Grant number: NNF10CC1016517). The authors would also like to thank the Writing Center - General Administration of the University - UNICAMP - for the language services provided (for co-authored studies).

\section{References}

[1] AOAC, 1997. AOAC Official Methods of Analysis of the Association of Official Analytical Chemistry, 16th ed. AOAC International, Gaithersburg, USA.

[2] APHA, 1998. Standard Methods for the Examination of Water and Wastewater American Public Health Association. Washington DC.

[3] Ariunbaatar, J., Panico, A., Esposito, G., Pirozzi, F., Lens, P.N., 2014. Pretreatment methods to enhance anaerobic digestion of organic solid waste. Appl. Energy. 123, 143-156.

[4] Ariunbaatar, J., Di Perta, E.S., Panico, A., Frunzo, L., Esposito, G., Lens, P.N., Pirozzi, F., 2015. Effect of ammoniacal nitrogen on one-stage and two-stage anaerobic digestion of food waste. Waste Manage. 38, 388398.

[5] Campuzano, R., Gonzalez-Martinez, S., 2015. Extraction of soluble substances from organic solid municipal waste to increase methane production. Bioresour. Technol. 178, 247-253

[6] Cappai, G., De Gioannis, G., Muntoni, A., Polettini, A., Pomi, R., Spiga, D., 2015. Effect of inoculum to substrate ratio (ISR) on hydrogen production through dark fermentation of food waste. In Atti del "Sardinia
2015 15th International Waste Management and Landfil Symposium. 5-9.

[7] Chandra, R., Takeuchi, H., Hasegawa, T., 2012. Methane production from lignocellulosic agricultural crop wastes: a review in context to second generation of biofuel production. Renew. Sust. Energy Rev. 16(3), 1462-1476

[8] Cheng, J., Liu, B., 2002. Swine wastewater treatment in anaerobic digesters with floating medium. Transactions of the ASAE. 45(3), 799-805

[9] Chu, C.F., Li, Y.Y., Xu, K.Q., Ebie, Y., Inamori, Y., Kong, H.N., 2008. A pH- and temperature-phased two-stage process for hydrogen and methane production from food waste. Int. J. Hydrogen Energy. 33(18), 4739-4746.

[10] Dareioti, M.A., Kornaros, M., 2015. Anaerobic mesophilic codigestion of ensiled sorghum, cheese whey and liquid cow manure in a two-stage CSTR system: effect of hydraulic retention time. Bioresour. Technol. 175, 553-562.

[11] Gao, S., Huang, Y., Yang, L., Wang, H., Zhao, M., Xu, Z., Huang, Z., Ruan, W., 2015. Evaluation the anaerobic digestion performance of solid residual kitchen waste by $\mathrm{NaHCO}_{3}$ buffering. Energy Convers. Manage. 93, 166-174.

[12] Gomez-Romero, J., Gonzalez-Garcia, A., Chairez, I., Torres, L. García-Peña, E.I., 2014. Selective adaptation of an anaerobic microbial community: biohydrogen production by co-digestion of cheese whey and vegetables fruit waste. Int. J. Hydrogen Energy. 39(24), 12541-12550.

[13] Gurgel, M.N., Correa, S.T., Dourado Neto, D.U.R.V.A.L., Júnior, P., 2015. Technology for sugarcane agroindustry waste reuse as granulated organomineral fertilizer. Engenharia Agrícola. 35(1), 63 75

[14] Han, W., Liu, D.N., Shi, Y.W., Tang, J.H., Li, Y.F., Ren, N.Q., 2015. Biohydrogen production from food waste hydrolysate using continuous mixed immobilized sludge reactors. Bioresour. Technol. $180,54-58$.

[15] Jabeen, M., Yousaf, S., Haider, M.R., Malik, R.N., 2015. High-solids anaerobic co-digestion of food waste and rice husk at different organic loading rates. Int. Biodeterior. Biodegrad. 102, 149-153.

[16] Kothari, R., Pandey, A.K., Kumar, S., Tyagi, V.V., Tyagi, S.K., 2014 Different aspects of dry anaerobic digestion for bio-energy: an overview. Renew. Sust. Energy Rev. 39, 174-195.

[17] Kythreotou, N., Florides, G., Tassou, S.A., 2014. A review of simple to scientific models for anaerobic digestion. Renewable Energy. 71 701-714.

[18] Li, L., Feng, L., Zhang, R., He, Y., Wang, W., Chen, C., Liu, G. 2015. Anaerobic digestion performance of vinegar residue in continuously stirred tank reactor. Bioresour. Technol. 186, 338-342.

[19] Lin, Y., Wu, S., Wang, D., 2013. Hydrogen-methane production from pulp \& paper sludge and food waste by mesophilic-thermophilic anaerobic co-digestion. Int. J. Hydrogen Energy. 38(35), $15055-$ 15062.

[20] Liu, X., Li, R., Ji, M., Han, L., 2013. Hydrogen and methane production by co-digestion of waste activated sludge and food waste in the two-stage fermentation process: substrate conversion and energy yield. Bioresour. Technol. 146, 317-323.

[21] Liu, X., Liu, H., Chen, Y., Du, G., Chen, J., 2008. Effects of organic matter and initial carbon-nitrogen ratio on the bioconversion of volatile fatty acids from sewage sludge. J. Chem. Technol. Biotechnol. 83(7), 1049-1055

[22] Mamimin, C., Singkhala, A., Kongjan, P., Suraraksa, B., Prasertsan, P., Imai, T., Sompong, O., 2015. Two-stage thermophilic fermentation and mesophilic methanogen process for biohythane production from palm oil mill effluent. Int. J. Hydrogen Energy. 40(19), 6319-6328.

[23] Montanes, R., Perez, M., Solera, R., 2013. Mesophilic anaerobic codigestion of sewage sludge and a lixiviation of sugar beet pulp optimisation of the semi-continuous process. Bioresour. Technol. $142,655-662$.

[24] Moraes, B.S., Zaiat, M., Bonomi, A., 2015. Anaerobic digestion of vinasse from sugarcane ethanol production in Brazil: challenges and perspectives. Renew. Sust. Energy Rev. 44, 888-903 
[25] Prochazka, J., Dolejs, P., Maca, J., Dohanyos, M., 2012. Stability and inhibition of anaerobic processes caused by insufficiency or excess of ammonia nitrogen. Appl. Microbiol. Biotechnol. 93(1), 439-447.

[26] Ratanatamskul, C., Onnum, G., Yamamoto, K., 2014. A prototype singlestage anaerobic digester for co-digestion of food waste and sewage sludge from high-rise building for on-site biogas production. Int. Biodeterior. Biodegrad. 95, 176-180.

[27] Rivero, M., Solera, R., Perez, M., 2014. Anaerobic mesophilic codigestion of sewage sludge with glycerol: enhanced biohydrogen production. Int. J. Hydrogen Energy. 39(6), 2481-2488.

[28] Shah, F.A., Mahmood, Q., Rashid, N., Pervez, A., Raja, I.A., Shah, M.M., 2015. Co-digestion, pretreatment and digester design for enhanced methanogenesis. Renew. Sust. Energy Rev. 42, 627-642.

[29] Stiegel, G.J., Ramezan, M., 2006. Hydrogen from coal gasification: An economical pathway to a sustainable energy future. Int. J. Coal Geol. 65(3-4), 173-190.

[30] Suwannarat, J., Ritchie, R.J., 2015. Anaerobic digestion of food waste using yeast. Waste Manage. 42, 61-66.
[31] Valdez-Vazquez, I., Ríos-Leal, E., Esparza-García, F., Cecchi, F., Poggi-Varaldo, H.M., 2005. Semi-continuous solid substrate anaerobic reactors for $\mathrm{H}_{2}$ production from organic waste: mesophilic versus thermophilic regime. Int. J. Hydrogen Energy. 30(13-14), 1383-1391.

[32] Xu, D.Y., Lin, Z.Y., Gordon, M.P.R., Robinson, N.K.L., Harder, M.K., 2016. Perceived key elements of a successful residential food waste sorting program in urban apartments: stakeholder views. J. Cleaner Prod. 134, 362-370.

[33] Zhu, H., Stadnyk, A., Beland, M., Seto, P., 2008. Co-production of hydrogen and methane from potato waste using a two-stage anaerobic digestion process. Bioresour. Technol. 99(11), 5078-5084.

[34] Zhu, H., Suzuki, T., Tsygankov, A.A., Asada, Y., Miyake, J., 1999 Hydrogen production from tofu wastewater by Rhodobacter sphaeroides immobilized in agar gels. Int. J. Hydrogen Energy. 24(4), 305-310. 